\title{
Assessing the biological reactivity of organic compounds on volcanic ash: implications for human health hazard
}

\author{
Ines Tomašek ${ }^{1,2}$ - David E. Damby ${ }^{3} \cdot$ Daniele Andronico $^{4} \cdot$ Peter J. Baxter ${ }^{5} \cdot$ Imke Boonen $^{1} \cdot$ Philippe Claeys $^{1}$. \\ Michael S. Denison $^{6}$. Claire J. Horwell ${ }^{7} \cdot$ Matthieu Kervyn $^{2} \cdot$ Ulrich Kueppers $^{8} \cdot$ Manolis N. Romanias $^{9} \cdot$ Marc Elskens $^{1}$
}

Received: 10 December 2020 / Accepted: 22 March 2021 / Published online: 8 April 2021

(c) The Author(s) 2021

\begin{abstract}
Exposure to volcanic ash is a long-standing health concern for people living near active volcanoes and in distal urban areas. During transport and deposition, ash is subjected to various physicochemical processes that may change its surface composition and, consequently, bioreactivity. One such process is the interaction with anthropogenic pollutants; however, the potential for adsorbed, deleterious organic compounds to directly impact human health is unknown. We use an in vitro bioanalytical approach to screen for the presence of organic compounds of toxicological concern on ash surfaces and assess their biological potency. These compounds include polycyclic aromatic hydrocarbons (PAHs), polychlorinated dibenzo$p$-dioxins and dibenzofurans (PCDD/Fs) and dioxin-like polychlorinated biphenyls (dlPCBs). Analysis of ash collected in or near urbanised areas at five active volcanoes across the world (Etna, Italy; Fuego, Guatemala; Kelud, Indonesia; Sakurajima, Japan; Tungurahua, Ecuador) using the bioassay inferred the presence of such compounds on all samples. A relatively low response to PCDD/Fs and the absence of a dIPCBs response in the bioassay suggest that the measured activity is dominated by PAHs and PAH-like compounds. This study is the first to demonstrate a biological potency of organic pollutants associated with volcanic ash particles. According to our estimations, they are present in quantities below recommended exposure limits and likely pose a low direct concern for human health.
\end{abstract}

Keywords Volcanic ash · Urban pollution · Health hazard · Organic compounds · Bioreactivity · CALUX bioassay

\section{Introduction}

Volcanic ash is a product of explosive volcanic eruptions and lava dome collapses and poses a threat to human health, infrastructure, air traffic and agriculture (Wilson et al. 2012,

Editorial responsibility: C.E.Gregg

Ines Tomašek

ines.tomasek@vub.be

1 Analytical, Environmental and Geochemistry Group (AMGC), Department of Chemistry, Vrije Universiteit Brussel, 1050 Brussels, Belgium

2 Physical Geography Group (FARD), Department of Geography, Vrije Universiteit Brussel, 1050 Brussels, Belgium

3 Volcano Science Center, United States Geological Survey (USGS), Menlo Park, CA 94025, USA

4 Istituto Nazionale di Geofisica e Vulcanologia (INGV), Osservatorio Etneo - Sezione di Catania, Catania, Italy
2015). Ash can reach, and potentially affect, communities hundreds of kilometres from a volcano (Martin et al. 2009), and often remains in the environment for months or even years following deposition (Durant et al. 2012). Hence, people can be exposed to ash in the aftermath of an eruption but also later, due to resuspension by wind or human activity (Jarvis et al. 2020). The respiratory health effects following

5 Institute of Public Health, University of Cambridge School of Clinical Medicine, Cambridge CB2 OSR, UK

6 Department of Environmental Toxicology, University of California-Davis, Davis, CA 95616, USA

7 Institute of Hazard, Risk \& Resilience, Department of Earth Sciences, Durham University, Durham DH1 3LE, UK

8 Department for Earth and Environmental Sciences, Ludwig-Maximilians-Universität München, 80333 Munich, Germany

9 IMT Lille Douai, SAGE, University Lille, 59000 Lille, France 
inhalation of volcanic ash are a long-standing and continuous global concern (Horwell and Baxter 2006; UNISDR 2015). Occurrence of respiratory symptoms varies among studies, but it is relatively clear that acute exposure to volcanic ash can exacerbate pre-existing respiratory diseases, such as asthma and bronchitis (Horwell and Baxter 2006).

With many volcanoes situated near large cities (Heiken 2013), ash frequently interacts with the atmosphere and associated anthropogenic pollution before being inhaled. Accordingly, populations are commonly exposed to volcanic ash concomitantly with additional substances, notably urban air pollutants such as vehicle and industry emissions, which are composed of a mixture of particulate matter and gaseous/volatile species. Currently, limited understanding exists regarding the human health hazards associated with the combined exposures to volcanic particulate matter and the polluted urban environment (Tomašek et al. 2016, 2018). Of particular importance is how volcanic ash interacts with urban pollutants and if this association may influence its biological reactivity and, in this way, contribute to an increase in adverse health effects for exposed populations.

Upon injection into the atmosphere, ash undergoes various physicochemical processes during transport and deposition that change its surface composition and reactivity (Ayris and Delmelle 2012). Studies have recognised the role of volcanic ash in the scavenging of volatiles (such as sulphur and halogen gases and metals) from the atmosphere and in the dispersal of adsorbed materials into the environment (Witham et al. 2005; Ayris and Delmelle 2012). Ash particles may also interact with anthropogenic pollution, which can be substantial in urbanised areas. We hypothesise that, during this process, organic compounds of toxicological concern to human health, such as dioxins (polychlorinated dibenzo- $p$-dioxins and dibenzofurans; $\mathrm{PCDD} / \mathrm{Fs}$ ), dioxinlike polychlorinated biphenyls (dlPCBs), polycyclic aromatic hydrocarbons (PAHs) and PAH-like compounds can be adsorbed onto ash surfaces.

Dioxins and dioxin-like compounds are ubiquitous environmental pollutants, characterised by high chemical stability, long-range transport and dispersal capability, low solubility in water and a tendency to accumulate in the environment (Jones and De Voogt 1999). Human exposure to PCDD/Fs and PCBs (via inhalation and ingestion of contaminated food) has been linked to a wide variety of health effects, including developmental and reproductive defects, alterations in immune function, cardiovascular disease and cancer (White and Birnbaum 2009; WHO 2019). These compounds are mainly formed as unintended by-products of anthropogenic activities such as industrial, municipal and domestic incineration and combustion processes (Safe 1998; Anderson and Fisher 2002), and PCBs have been produced commercially in the past (Voogt and Brinkman 1989). Although banned worldwide, PCBs continue to be used in operating electrical equipment (e.g. transformers and capacitors) which have a limited service life (Harrad et al. 1994). There is evidence that dioxins are emitted from natural sources, such as wildfires (Crummett 1982; Meyer et al. 2004), to a much smaller extent, but no studies demonstrating their formation in volcanic eruptions have been published. Pyrolysis of vegetation, combustion processes and urban traffic are also responsible for the production of PAHs (Pereira et al. 1980; Howsam and Jones 1998), which are well known for their negative health implications, notably their genotoxic and carcinogenic potential (IARC 1983; Rengarajan et al. 2015).

It has been recognised that inhalation of particles with such adhered organic species can affect particle-cell interactions and can cause damage to lung cells and tissues (Fubini 1997; Knaapen et al. 2004). There is, thus, reasonable cause for concern if they are delivered to the body bound to the surface of volcanic ash particles following a volcanic eruption. Yet, compared to the other adsorbed hazards usually analysed on volcanic ash (e.g. potentially toxic elements such as As, Fe, Pb, F) (Stewart et al. 2020), the presence of persistent organic pollutants on ash surfaces and their potential impact on the health hazard have been poorly investigated, to date. Only a limited number of studies have identified PCDD/Fs, PCBs and PAHs adsorbed onto volcanic ash, which were shown to originate from anthropogenic sources (Lamparski et al. 1990; Takizawa et al. 1994; Stracquadanio et al. 2003; Guiñez et al. 2020), but none has considered their in situ reactivity and the consequential impact of exposure to such particles on human (and environmental) health.

The aim of this study was to screen volcanic ash for the presence of deleterious organic compounds typical of urban environments (such as PCDDs/Fs, PCBs and PAHs) and estimate their bioreactivity using an in vitro bioanalytical approach. We utilised a reporter-gene cell-based bioassay, the Chemically Activated LUciferase gene eXpression (CALUX) (Denison et al. 2004), which is based on the interaction of compounds with the aryl hydrocarbon receptor (AhR), a protein that is responsible for mediating the toxic and biological effects of diverse organic compounds (Denison et al. 2011). We assayed a selection of volcanic ash samples collected near urbanised areas from active volcanoes (Etna, Italy; Fuego, Guatemala, Kelud, Indonesia; Sakurajima, Japan and Tungurahua, Ecuador) to determine whether the occurrence of organic compounds on ash is common. The experiments provide the first direct evidence of the biological potency of ashassociated organic compounds and provide an avenue in which to investigate the potential health implications of their association. 


\section{Materials and methods}

\section{Volcanic ash samples}

We selected five active volcanoes for this study, ranging in magma composition and eruption styles: Etna - ET, Fuego - FU, Kelud - KE, Sakurajima - SA and Tungurahua - TU (Table 1). The ash samples are from variable proximities to urban areas and include samples ranging from pristine (freshly erupted samples that have not been rained on) to older deposits (exposed to meteorological conditions for a few weeks or months; Table 1). Samples were not collected specifically for this study but were provided in varying amounts and analysed in their bulk (un-sieved) form, except for samples TU1 and SA1, which were provided in dry-sieved fractions $<63 \mu \mathrm{m}$ and $<125 \mu \mathrm{m}$, respectively. We acknowledge this as a limitation of the study as, ideally, the analysed samples would be of a consistent size fraction and one that directly reflects the respiratory hazard, such as the 'respirable' fraction, which is defined as particles that can penetrate to, and deposit in, the deep lung (sub-4- $\mu \mathrm{m}$ aerodynamic diameter) (ISO 1995). However, isolation of respirable material from bulk ash (as in Tomašek et al. 2016) in amounts sufficient for this analysis was not possible due to the varying quantities of sub-4- $\mu \mathrm{m}$ material among the samples and limited amounts of volcanic ash available for the study. It is important to note that organic compounds have been found to be enriched in the finer fractions of other particulate matter (Nessel et al. 1992; Kaupp and McLachlan 2000), so our measured values (section 'CALUX analysis of volcanic ash') may be a low estimate.

Particle size distributions and specific surface areas were assessed on sub-samples for all ash samples in the study. Particle size distributions were determined using a Coulter LS230 (Beckman Coulter Inc., USA) in water without sonication, at the Vrije Universiteit Brussel, Belgium. Data were analysed according to the Mie theory of light scattering, with a refractive index set to 1.63 and an absorption coefficient of 0.1 (Horwell 2007). Results are the mean of three consecutive runs of the sample. Specific surface area (SSA) was determined according to the BET method (Brunauer et al. 1938) and analysed by nitrogen adsorption using a custom-made laboratory gas sorption analysis system at the University of Lille, France (Joshi et al. 2017). Results are the mean of three independent measurements of the sample.

\section{CALUX bioassay}

The CALUX bioassay uses a mammalian cell line that is genetically modified to produce a quantifiable response following activation of the AhR signalling pathway. Activation of AhR by a compound results in induction of a reporter gene (luciferase) within the cells and the activity of the resulting enzyme (luciferase) produces light which is quantified using a luminometer. The amount of induced luciferase is directly proportional to the amount and potency of the AhR-active
Table 1 Sample and collection information for the volcanic ash samples analysed in this study. Samples range from pristine (freshly erupted samples that have not been rained on) to older deposits (exposed to meteorological conditions for few weeks or months; so were either not fresh or were rained on). $P D C$, pyroclastic density current

\begin{tabular}{|c|c|c|c|c|c|c|c|c|c|}
\hline Sample name & Volcano & Eruption date & $\begin{array}{l}\text { Collection } \\
\text { date }\end{array}$ & $\begin{array}{l}\text { Type of } \\
\text { activity }\end{array}$ & Magma type & $\begin{array}{l}\text { Collection } \\
\text { location }\end{array}$ & $\begin{array}{l}\text { Distance } \\
\text { from vent } \\
(\mathrm{km})\end{array}$ & $\begin{array}{l}\text { Collection } \\
\text { environ- } \\
\text { ment }\end{array}$ & $\begin{array}{l}\text { State of } \\
\text { sample }\end{array}$ \\
\hline ET1 & Etna & 03-Nov-02 & 03-Nov-02 & Strombolian & Trachybasalt & Catania, Italy & 25.4 & Urban & Pristine \\
\hline ET2 & & 11-Dec-02 & 11-Dec-02 & Strombolian & Trachybasalt & Catania, Italy & 26.7 & Urban & Pristine \\
\hline FU1 & Fuego & 03-Jun-18 & 24-Oct-18 & Paroxysmal & Basalt & $\begin{array}{l}\text { Alotenango, } \\
\text { Guatemala }\end{array}$ & 7.3 & Urban & Not fresh \\
\hline KE1 & Kelud & $\begin{array}{l}\text { 13-15-Feb- } \\
14\end{array}$ & 15-Feb-14 & Plinian & Andesite & $\begin{array}{c}\text { Yogyakarta, } \\
\text { Indonesia }\end{array}$ & 210 & Urban & Pristine \\
\hline KE2 & & $\begin{array}{l}\text { 13-15-Feb- } \\
14\end{array}$ & 01-Apr-14 & Plinian & $\begin{array}{l}\text { Basaltic } \\
\text { andesite }\end{array}$ & $\begin{array}{c}\text { Yogyakarta, } \\
\text { Indonesia }\end{array}$ & 210 & Urban & Rained on \\
\hline SA1 & Sakurajima & 18-Jul-13 & 18-Jul-13 & $\begin{array}{l}\text { Vulcanian; } \\
\text { co-PDC } \\
\text { ash }\end{array}$ & Andesite & $\begin{array}{l}\text { Kurokami } \\
\text { Observa- } \\
\text { tory, Japan }\end{array}$ & 4 & Suburban & Pristine \\
\hline SA2 & & 31-Oct-10 & 31-Oct-10 & Vulcanian & Andesite & $\begin{array}{l}\text { Arimura } \\
\text { Observa- } \\
\text { tory, Japan }\end{array}$ & 2.3 & Suburban & Pristine \\
\hline TU1* & Tungurahua & 02-Feb-14 & 07-Feb-14 & $\begin{array}{l}\text { sub-Plinian; } \\
\text { co-PDC } \\
\text { ash }\end{array}$ & Andesite & $\begin{array}{l}\text { Los } \\
\text { Pacharos, } \\
\text { Ecuador }\end{array}$ & 6 & Rural & Pristine \\
\hline
\end{tabular}

${ }^{*}$ The sample TU1 is also called 14TUN05 in other publications using the same sample (Müller et al. 2020; Yang et al. 2020) 
compounds to which the cells have been exposed (Denison et al. 2004; Windal et al. 2005).

This bioassay is widely applied for screening and monitoring of diverse biological and environmental materials, including atmospheric particulates (Denison et al. 2004; Gizzi et al. 2005; Khedidji et al. 2017), and offers a novel strategy for volcanic material characterisation. In comparison to conventional chromatography techniques, CALUX is a rapid and relatively cost-effective semi-quantitative screening method, which provides an integrated effect-based biological response of all compounds present in the sample extract that can bind to and activate the AhR. Thus, CALUX enables fast identification of samples containing chemicals of potential concern, and it is useful for making timely and informed decisions on the need for further analyses by chromatography techniques.

In this study, the CALUX bioassay was conducted using both crude (total) volcanic ash extracts (samples containing all extracted compounds) to determine the total AhR activity for a sample, and cleaned-up ash extracts (samples with PCDD/ Fs and dIPCBs isolated from the total extracts) to determine the contribution of PCDD/Fs and dlPCBs to the total AhR activity. The analyses of crude extracts for total AhR activity were conducted on three replicate ash samples (i.e. three separate ash extractions). The analyses of cleaned-up extracts for PCDD/Fs and dIPCBs were done on three replicate samples for FU1 and KE2 but only on a single replicate sample for all other samples due to the limited amounts of volcanic ash available for the study.

Each sample extract was then tested in 10 concentrations (in triplicate) to establish a concentration-response curve (see 'Results' section, Figs. 2 and 3) by plotting the measured luciferase activity (luminescence) expressed as a fold change from the assay background value. The response induced by each sample was then compared to the response of reference compounds, which were used to derive standard curves. These reference compounds were benzo[a]pyrene $(\mathrm{BaP})$ for total $\mathrm{AhR}$ activity (crude extracts), and 2,3,7,8-tetrachlorodibenzo- $p$-dioxin (TCDD; the most potent dioxin congener) for PCDD/Fs and dIPCBs (cleaned-up extracts). Through this comparison, the AhR activity of a sample was converted into bioanalytical equivalent (BEQ) concentration and expressed as ng $\mathrm{BaP}$ or pg TCDD equivalent per $\mathrm{g}$ of ash dry weight (see 'Results' section, Table 4). We refer the reader to Appendix 1 for a detailed methodology on ash extraction, clean-up, AhR-CALUX procedures and data analysis.

\section{Results}

\section{Volcanic ash properties}

Particle size analysis showed that all the samples except ET2 contain inhalable (sub-100 $\mu \mathrm{m}$ ) particles, at varying volume percentages (Fig. 1, Table 2). The SSA of samples varied among the samples and ranged from 0.07 to $1.84 \mathrm{~m}^{2} / \mathrm{g}$ (Table 3).

\section{CALUX analysis of volcanic ash}

Illustrative concentration-response curves (relative response as a function of the concentration) for crude and cleaned-up extracts of samples, and their corresponding standard curves, are shown in Figs. 2 and 3, respectively. All crude extracts induced a response in the bioassay, indicating the presence of AhR-active compounds on each of the ash samples (Fig. 2). Relative response levels calculated for these sample extracts ranged between 6 and $21 \mathrm{ng} \mathrm{BaP} \mathrm{BEQ/g,} \mathrm{with}$ the exception of sample KE2, which was the most potent, with a BEQ of $122 \mathrm{ng} \mathrm{BaP} \mathrm{BEQ/g} \mathrm{(Table} \mathrm{4).} \mathrm{Low} \mathrm{levels} \mathrm{of}$ AhR activation were detected in the PCDD/Fs fraction of the cleaned-up sample extracts (Fig. 3), with response levels ranging between 0.2 and $0.6 \mathrm{pg}$ TCDD BEQ/g (Table 4). The highest activities were measured in samples FU1 and KE2, with a BEQ of 0.3 and $0.6 \mathrm{pg}$ TCDD BEQ/g, respectively (Fig. 3, Table 4). The dlPCBs fraction of the cleaned-up samples showed no detectable activity in the bioassay (data not shown), indicating the absence of dlPCBs or their presence below detectable levels in analysed samples.

\section{Discussion}

\section{Bioreactivity of organic compounds on volcanic ash}

AhR is known to be activated by a wide range of structurally diverse chemicals (DeGroot et al. 2011), notably a very large and diverse collection of PAHs and chlorinated aromatics (Machala et al. 2001; Ziccardi et al. 2002; Ohura et al. 2007). The low level of AhR activity in the cleanedup PCDD/Fs fraction ( $<0.6 \mathrm{pg}$ TCDD BEQ/g) and lack of activity in the dIPCBs fraction indicates that the chemicals in these fractions (e.g. chlorinated, brominated and mixed chloro/bromo dibenzo- $p$-dioxins, dibenzofurans, biphenyls and related halogenated aromatic hydrocarbons) contribute little to the overall AhR activity of the total extract, where response levels were up to $122 \mathrm{ng} \mathrm{BaP} \mathrm{BEQ/g}$. This suggests that the vast majority of the total measured AhR activity can be attributed to PAHs and PAH-like compounds. This observation is supported by past identification of PAHs on volcanic ash (Pereira et al. 1980; Stracquadanio et al. 2003; Guiñez et al. 2020) and the fact that they are typically far more abundant in the environment (Lohmann et al. 2000).

Direct comparison of our data with those of previous studies that measured organic compounds on volcanic ash is hindered by the use of different methods and associated differences in concentration reporting. Previous studies 
Fig. 1 Particle size distributions of ash samples from Etna (ET), Fuego (FU), Kelud (KE), Sakurajima (SA) and Tungurahua (TU) volcanoes. (a) Cumulative particle size distributions and (b) particle size distributions of samples. Lines represent the mean of three measurement cycles recorded for each sample

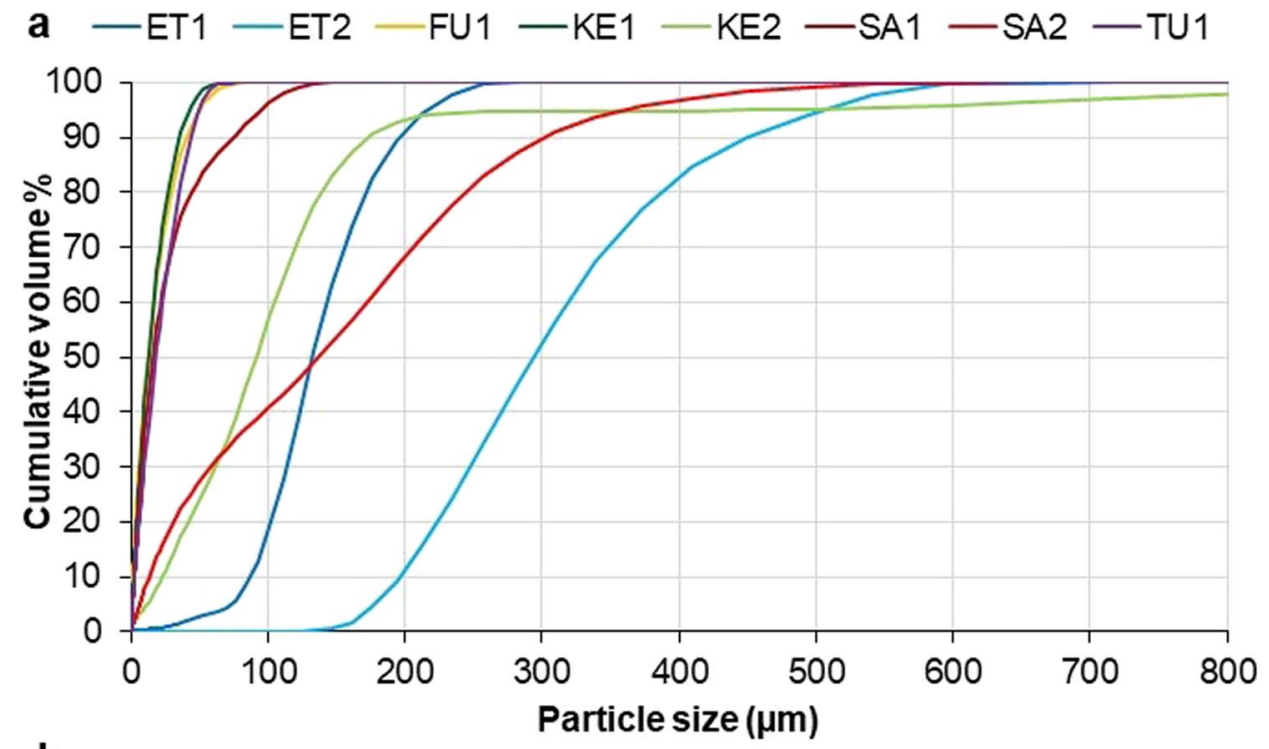

b

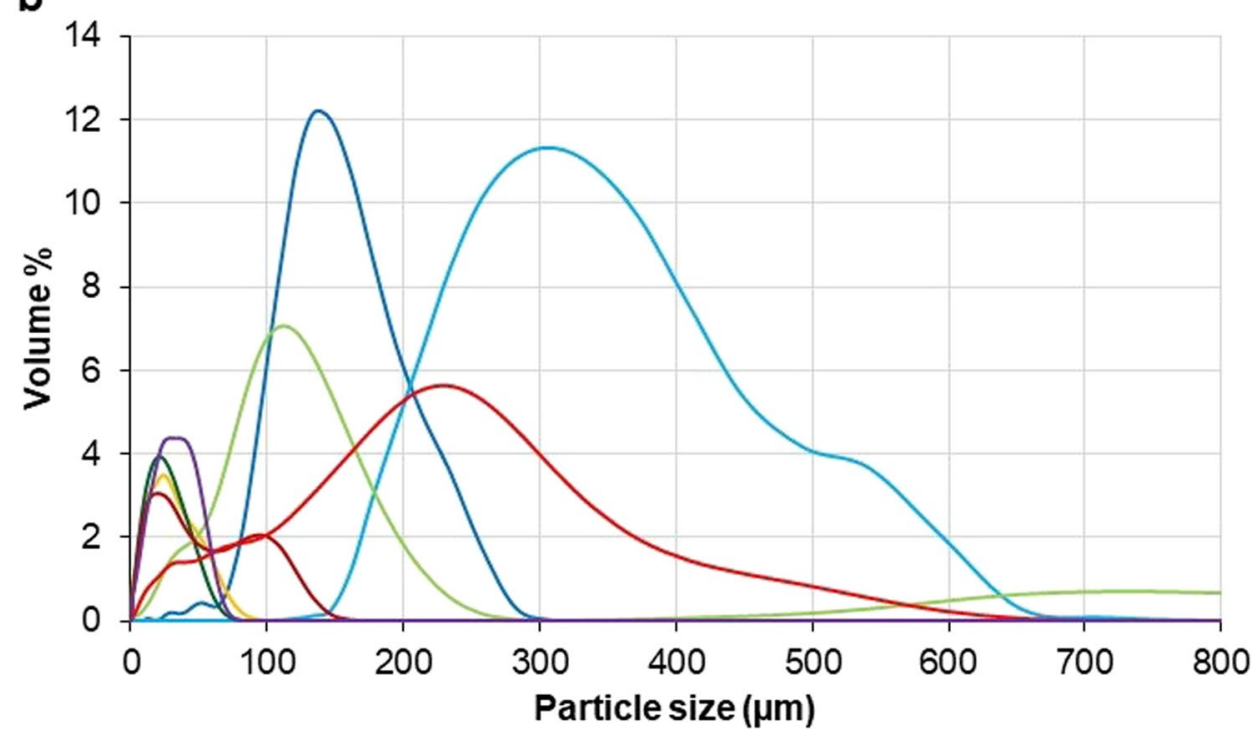

utilised instrumental analysis techniques, namely gas chromatography/high-resolution mass spectrometry (Pereira et al. 1980; Takizawa et al. 1994; Kozak et al. 2017) and

Table 2 Particle size information at health-relevant size fractions for the analysed samples. Data are the mean of $n=3$

\begin{tabular}{llrrrr}
\hline & \multicolumn{5}{l}{ Particle size $(\mu \mathrm{m}$; cumulative vol. \%) } \\
\cline { 2 - 6 } Sample & $<1$ & $<2.5$ & \multicolumn{1}{c}{$<4$} & $<10$ & $<100$ \\
\hline ET1 & 0.04 & 0.11 & 0.18 & 0.28 & 18.38 \\
ET2 & 0.00 & 0.00 & 0.00 & 0.00 & 0.00 \\
FU1 & 6.74 & 16.76 & 23.06 & 43.16 & 100.00 \\
KE1 & 4.93 & 12.65 & 19.19 & 41.43 & 99.98 \\
KE2 & 1.05 & 1.97 & 2.50 & 4.33 & 56.62 \\
SA1 & 3.49 & 10.59 & 16.37 & 35.75 & 96.18 \\
SA2 & 0.97 & 2.12 & 3.16 & 7.68 & 40.80 \\
TU1 & 2.90 & 9.38 & 14.19 & 30.45 & 99.99 \\
\hline
\end{tabular}

high-performance liquid chromatography (Stracquadanio et al. 2003; Guiñez et al. 2020), which allow the identification and quantification of individual chemicals in sample extracts, but provide no direct information on sample bioreactivity. Only Takizawa et al. (1994) reported their

Table 3 Specific surface area (SSA) of ash samples used in the study. Data are the mean of $n=3 \pm$ standard deviation

\begin{tabular}{ll}
\hline Sample & SSA $\left(\mathrm{m}^{2} / \mathrm{g}\right)$ \\
\hline ET1 & $0.07 \pm 0.04$ \\
ET2 & $0.11 \pm 0.03$ \\
FU1 & $1.36 \pm 0.05$ \\
KE1 & $0.82 \pm 0.06$ \\
KE2 & $0.54 \pm 0.10$ \\
SA1 & $0.81 \pm 0.11$ \\
SA2 & $1.84 \pm 0.07$ \\
TU1 & $0.73 \pm 0.19$ \\
\hline
\end{tabular}




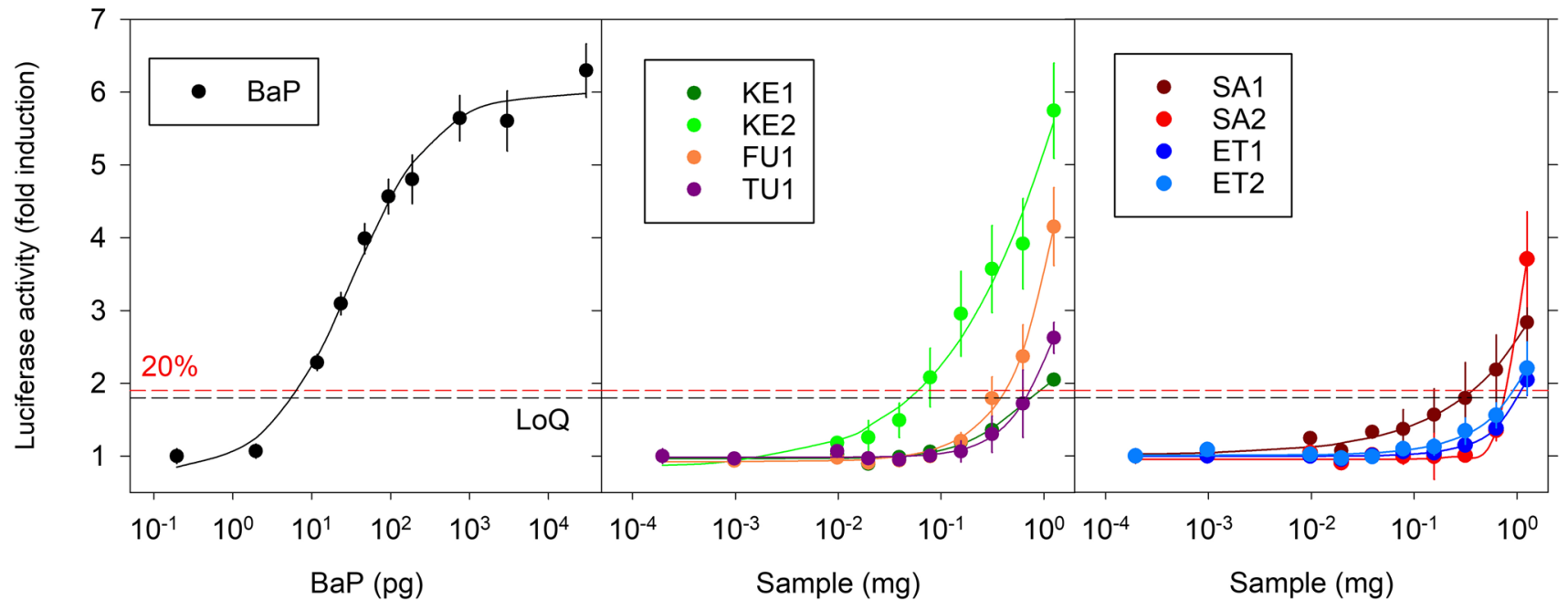

Fig. 2 Luciferase induction in cells by BaP (reference compound) and volcanic ash crude (total) extracts as determined by CALUX. The figure shows illustrative concentration-response curves for BaP standard and volcanic ash crude extracts (total AhR activity). Luciferase activity of $\mathrm{BaP}$ and samples was expressed as a fold change from the

findings on Sakurajima ash as TCDD toxicity equivalents (TEQs), which generally correlate well with CALUX BEQs (US EPA 2014a). They found PCDD/Fs concentrations of approximately $0.03 \mathrm{pg}$ TCDD TEQ/g ( $5 \mathrm{pg} / \mathrm{g}$ ash), which are much lower than those in the Sakurajima ash analysed here (0.23 pg TCDD BEQ/g; Table 4). Our finding of AhR activity in Etna samples is in agreement with past reports from Stracquadanio et al. (2003) who also analysed ash from Etna, including a sample collected in Catania, Italy. From their samples, they reported concentrations of eight PAHs background value. The red dashed line represents the induction $(20 \%$, at 1.9-fold change) used to derive the BEQ value for the samples. Limit of quantification (LoQ) was equal to 1.8-fold change (the black dashed line)

(from the US EPA Priority Pollutant List; US EPA 1982) ranging from 0.2 to $20 \mathrm{ng} / \mathrm{g}$ ash, the majority of which are known to activate the AhR signalling pathway.

No correlation was observed between our BEQ values and the physical properties measured (sample SSA, Fig. A2.1, and particle size distributions, Fig. A2.2; see Appendix 2). Ash chemical properties, such as surface composition and reactivity, are central to the uptake of atmospheric/ambient species (Maters et al. 2016; Urupina et al. 2019) and may also play a role in adsorption of the organic compounds

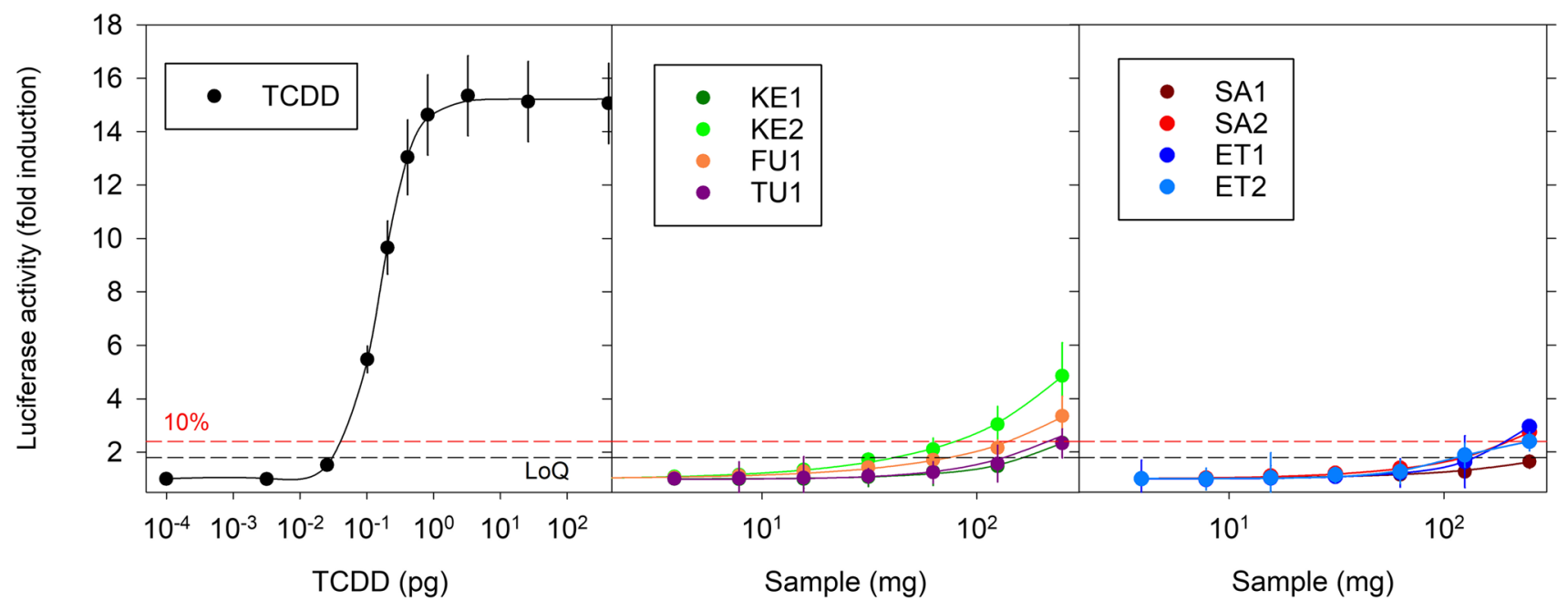

Fig. 3 Luciferase induction in cells by TCDD (reference compound) and PCDD/Fs from volcanic ash extracts as determined by CALUX. Illustrative concentration-response curves for TCDD standard and $\mathrm{PCDD} / \mathrm{Fs}$ fractions of sample extracts. Luciferase activity of sam- ples was expressed as a fold change from the background value. The red dashed line represents the induction (10\%, at 2.4-fold change) used to derive the BEQ value for the samples. Limit of quantification (LoQ) was equal to 1.8-fold change (the black dashed line) 
tested here. Such an exhaustive ash surface characterisation may provide further information regarding sequestration or exposure but was beyond the scope of this bioanalytical screening study. Therefore, we cannot comment further on the influence of ash properties on the adsorption of organic compounds. However, considering the finding of AhR-active compounds in both pristine and non-pristine ash samples (Table 4), and the lack of correlation found with physical properties, we assume that the observed variability in the amounts of adsorbed pollutants is due, at least in part, to varying atmospheric composition (i.e. pollutant concentrations), on the spatial- and temporal-scale. Concentrations of PCDD/Fs and PAHs in the ambient air highly depend on the (local) emission rates and environmental conditions (Lohmann and Jones 1998; Ravindra et al. 2008) which, in turn, would impact adsorbed abundances. KE2 had by far the highest measured AhR activity in crude extract (122 ng $\mathrm{BaP} \mathrm{BEQ} / \mathrm{g}$ ), and this sample was collected several weeks following the eruption (Table 1). Another non-pristine sample analysed in this study, FU1, exhibited relatively high total AhR activity (16 ng BaP BEQ/g). This suggests that a longer residence time in the environment (i.e. in ashfall deposited prior to collection) may lead to greater adsorption of organic pollutants onto ash surfaces. However, it remains to be investigated if the adsorption indeed occurs mostly after deposition or during airborne transport. The specific influence of sample history offers another promising avenue to explore and is particularly relevant for long-term exposure to resuspended ash (Jarvis et al. 2020).

\section{Implications for human health}

Most of the analysed samples contain inhalable (sub$100 \mu \mathrm{m})$ particles, ranging from 18 to $100 \%$ by volume (Fig. 2), which indicates their potential to be inhaled. The percentage of respirable (sub-4 $\mu \mathrm{m}$ ) particles varied among samples ( $0.1-23 \%$ by volume; Table 2$)$. This variability in fine particle content reflects multiple factors, including, but not limited to, the sample collection distance from the vent and the magnitude and explosivity of the eruption (Horwell and Baxter, 2006; Horwell 2007). The mass of respirable ash that deposits in the lungs from exposure is difficult to estimate, owing to a lack of empirical data on real-life exposure levels. Airborne ash concentrations are rarely measured and personal exposure to volcanic ash is highly influenced by the activities undertaken by individuals, including the use of exposure reduction measures (e.g. staying indoors, wearing facemasks) (Searl et al. 2002; Horwell et al. 2003; Steinle et al. 2018). Furthermore, the depositional efficiency of ash in the lung as a poly-disperse granular material is largely unconstrained (Lahde et al. 2013). However, it is informative to contextualise the BEQ values determined in this study, and some assumptions can be made to allow an evaluation of the potential health hazard.

For this purpose, we calculated a daily intake of PCDD/Fs and PAHs via inhalation of volcanic ash. We based the calculation on a daily inhaled air volume of $20 \mathrm{~m}^{3}$, defined for an adult (US EPA 2014b), an assumed 2-h daily exposure to airborne ash concentrations of 0.02 and $1 \mathrm{mg} / \mathrm{m}^{3}$, which correspond to a case example of minimum and maximum daily averages (Searl et al. 2002), and a lung deposition efficiency for ash of 10\% (Lahde et al. 2013). Use of the maximum BEQ for PCDD/Fs measured in this study (0.6 pg TCDD $\mathrm{BEQ} / \mathrm{g}$ ) equates to inhalation of $1 \times 10^{-4} \mathrm{pg}$ TCDD BEQ/ day when ambient concentrations of ash are high $\left(1 \mathrm{mg} / \mathrm{m}^{3}\right)$ and $2 \times 10^{-6}$ pg TCDD BEQ/day when ambient concentrations are low $\left(0.02 \mathrm{mg} / \mathrm{m}^{3}\right)$. The maximum BEQ for PAHs measured in the study (122 $\mathrm{ng} \mathrm{BaP} \mathrm{BEQ/g}$ ) equates to a daily intake of $20.4 \mathrm{pg} \mathrm{BaP} \mathrm{BEQ}$ and $0.4 \mathrm{pg} \mathrm{BaP} \mathrm{BEQ}$ for high and low concentrations of airborne ash, respectively.
Table 4 CALUX analysis results expressed as bioanalytical equivalent concentration $(\mathrm{BEQ} \pm$ the standard error (SE) and relative standard error (RSE)) on a per mass and surface area basis relative to $\mathrm{BaP}$ for total $\mathrm{AhR}$ activity $\left(\mathrm{ng} / \mathrm{g}\right.$ and $\left.\mathrm{ng} / \mathrm{m}^{2}\right)$ and relative to TCDD for PCDD/Fs (pg/g and $\mathrm{pg} / \mathrm{m}^{2}$ )

\begin{tabular}{|c|c|c|c|c|c|c|}
\hline \multirow[b]{2}{*}{ Sample } & \multicolumn{3}{|c|}{ Crude extract (total AhR activity) } & \multicolumn{3}{|c|}{ Cleaned-up extract (PCDD/Fs*) } \\
\hline & $\begin{array}{l}\text { ng BEQ BaP/g } \\
\left( \pm \mathrm{SE}^{\mathrm{a}}\right)\end{array}$ & RSE \% & BEQ ng $/ \mathrm{m}^{2}$ & $\begin{array}{l}\mathrm{pg} \mathrm{BEQ} \\
\mathrm{TCDD} / \mathrm{g} \\
\left( \pm \mathrm{SE}^{\mathrm{b}}\right)\end{array}$ & RSE \% & BEQ $\mathrm{pg} / \mathrm{m}^{2}$ \\
\hline ET1 & $6 \pm 0.7$ & 12 & 85.7 & $0.23 \pm 0.01$ & 6 & 3.29 \\
\hline ET2 & $7.3 \pm 1.1$ & 15 & 66.4 & $0.19 \pm 0.04$ & 21 & 1.73 \\
\hline FU1 & $16.4 \pm 2.2$ & 13 & 12.1 & $0.33 \pm 0.04^{\mathrm{a}}$ & 12 & 0.24 \\
\hline KE1 & $7.9 \pm 2.1$ & 27 & 9.6 & $0.18 \pm 0.01$ & 7 & 0.22 \\
\hline KE2 & $122 \pm 29$ & 24 & 225.9 & $0.6 \pm 0.07^{\mathrm{a}}$ & 12 & 1.11 \\
\hline SA1 & $21 \pm 6$ & 29 & 25.9 & $<\mathrm{LoQ}$ & - & - \\
\hline SA2 & $8.2 \pm 0.4$ & 5 & 4.5 & $0.23 \pm 0.02$ & 9 & 0.13 \\
\hline TU1 & $9.2 \pm 1.2$ & 13 & 12.6 & $0.18 \pm 0.02$ & 8 & 0.25 \\
\hline
\end{tabular}

SE was derived from either three independent ash extractions ${ }^{\mathrm{a}}$ or from three replicate measurements of a single extraction ${ }^{\mathrm{b}}$. ${ }^{*}$ The response for dIPCB fractions was below quantification limit (LoQ; Appendix 1) and therefore not expressed as BEQ 
Quantitative data on pulmonary bioavailability of PCDD/ Fs and PAHs following inhalation exposure in humans are limited, so we based the risk calculations on the assumption that $100 \%$ of the particle-bound dose is absorbed (Nessel et al. 1992). With insufficient toxicokinetic information for inhalation exposure, route-to-route extrapolation was made to ingestion, which is the main exposure route for organic contaminants. This was considered appropriate given that the critical effect is not specific to the site of application. Tolerable daily intakes (TDI) for ingestion of organic contaminants are normally expressed on a body-weight (bw) basis and are defined as the amount of a substance that can be ingested in a period of $24 \mathrm{~h}$ without appreciable health risk (WHO 1994). Calculated on the basis of default values for population body weight reported by the European Food Safety Authority (EFSA 2012), daily intakes for an adult (70 kg) of $\mathrm{PCDD} / \mathrm{Fs}$ for the high concentration of airborne ash equate to $1.4 \times 10^{-6} \mathrm{pg}$ TCDD BEQ/kg bw/day, whereas the intake of $\mathrm{PAHs}$ is $0.3 \mathrm{pg} \mathrm{BaP} \mathrm{BEQ} / \mathrm{kg}$ bw/day. Referencing the WHO guideline values of 10-40 $\mathrm{pg}$ of TCDD/kg bw/day (van Leeuwen et al. 2000) and $100 \mu \mathrm{g}$ of BaP/kg bw/day (JECFA 2006), the measured values are far below the TDI. Considering that the exposure to airborne ash is typically of limited duration, whereas the guidance values for health-based exposure limits relate to long-term exposure, it can be said that direct exposure to PCDD/Fs and PAHs via inhalation of ash likely represents a low immediate concern for human health.

\section{Future work perspectives}

Our study confirmed that ash can scavenge organic pollutants from the atmosphere which, upon ash deposition, may promote contact with soil, vegetation and water where they then can be taken up in the food chain (Dumortier et al. 2012). Ingestion of contaminated food represents the major route of human exposure to dioxins and dioxin-like compounds (Van den Berg et al. 2006). Adsorption onto ash is also a method by which these compounds can be spread over large geographical areas, especially if ash remains in the environment over a longer period of time. Once associated with particles, these compounds degrade slowly and may persist for many years, which has been demonstrated by measurements of PAHs, PCDD/Fs and dioxin-like compounds in soil, sediments and urban air particles (e.g. soot particles, road dust) (WHO 2000, 2019). The potential for volcanic ash to contribute to sediment concentrations of dioxin and dioxin-like compounds at our sampling locations would require a different analytical and sampling approach, but may be of potential future interest given these screening data.

The findings of our study open the opportunity for more detailed research. From the present results, it is not possible to directly elucidate the origin (volcanic or anthropogenic) of organic pollutants on ash nor can it be excluded that, in addition to volcanic particles, our samples may have contained some urban aerosol particles. A follow-up study should, therefore, implement an appropriate sampling strategy including environmental background sampling and, possibly, direct sample collection from the air. Moreover, a future study should investigate samples from a recent eruption, collected at different distance from the source volcano and at regular time intervals to elucidate the critical factors controlling the presence and abundance of organic compounds (e.g. grain size, ash composition, meteorological conditions, exposure to anthropogenic contamination).

\section{Conclusion}

This study provides the first evidence of the biological potency of organic pollutants associated with volcanic ash particles. We find bioactive PAHs and, to a lesser degree, PCDD/Fs associated with ash samples from five separate locations. According to our calculations, they are present in quantities below recommended exposure limits and, therefore, likely pose a low direct concern for human health. However, previous work has shown a synergistic toxic effect between volcanic ash and other organic constituents (Tomašek et al. 2016), and so these data should be considered in context. The findings of this first study provide a novel basis on which to understand the ways in which ash interacts with organic pollutants and how they may contribute to ash toxicity. This is crucial for a mechanistic understanding of ash toxicity, which is currently lacking.

Very little is known about the concentrations and origins of PAHs, dioxin-like compounds (PCDD/Fs and PCBs) and related chemicals on volcanic ash and their implications for human health. We were unable to correlate the specific influence of sample histories (eruption type, collection place and time) or physical properties of our ash samples (particle size distribution, specific surface area) with the measured abundance of organic compounds. However, our successful application of the AhR-CALUX bioassay to volcanic ash establishes a fast, costeffective method which, accompanied by systematic sampling, can be used in future studies to monitor the pollutant transport and deposition in the environment following an eruption. This represents an important step in the ongoing efforts to identify and characterise volcanic ash properties that may be of relevance for adverse health effects, and for the implementation of screening strategies for protecting communities affected by ashfall.

Supplementary Information The online version contains supplementary material available at https://doi.org/10.1007/s00445-021-01453-4. 
Acknowledgements We acknowledge Heather Wright (USGS) and Supriyati Andreastuti (CVGHM in Yogyakarta) for providing the Kelud ash sample. We are thankful to Alexa Van Eaton, two anonymous reviewers and associate editor Christopher Gregg for their constructive comments on this manuscript.

Author contribution Ines Tomašek: Conceptualisation, methodology, investigation, formal analysis, visualisation, writing — original draft. David E. Damby: Conceptualisation, writing — review and editing. Daniele Andronico: Resources, writing - review and editing. Peter J. Baxter: Writing — review and editing. Imke Boonen: Investigation, writing - review and editing. Philippe Claeys: Funding acquisition, conceptualisation, writing - review and editing, supervision. Michael S. Denison: Resources, writing — review and editing. Claire J. Horwell: Conceptualisation, resources, writing — review and editing. Matthieu Kervyn: Writing — review and editing, supervision. Ulrich Kueppers: Resources, writing — review and editing. Manolis N. Romanias: Investigation, writing - review and editing. Marc Elskens: Conceptualisation, formal analysis, writing — review and editing, supervision.

Funding This work was funded by a VUB Strategic Research Programme to PC-ME-MK and was supported by the Research Foundation Flanders grant to ME (FWOKN299). IT, CJH and UK acknowledge the support by the Marie Skłodowska-Curie Actions Initial Training Network 'VERTIGO', funded through the European Seventh Framework Programme (FP7 2007-2013) under Grant Agreement number 607905. The H1L7.5 cell line was developed by the University of CaliforniaDavis (USA) with funding from a Superfund Research Programme grant (ES04699) from the National Institute of Environmental Health Sciences.

Data availability The datasets generated during the current study are available from the corresponding author on reasonable request.

\section{Declarations}

Competing interests The authors declare no competing interests.

Disclaimer Any use of trade, firm or product names is for descriptive purposes only and does not imply endorsement by the US Government.

Open Access This article is licensed under a Creative Commons Attribution 4.0 International License, which permits use, sharing, adaptation, distribution and reproduction in any medium or format, as long as you give appropriate credit to the original author(s) and the source, provide a link to the Creative Commons licence, and indicate if changes were made. The images or other third party material in this article are included in the article's Creative Commons licence, unless indicated otherwise in a credit line to the material. If material is not included in the article's Creative Commons licence and your intended use is not permitted by statutory regulation or exceeds the permitted use, you will need to obtain permission directly from the copyright holder. To view a copy of this licence, visit http://creativecommons.org/licenses/by/4.0/.

\section{References}

Anderson DR, Fisher R (2002) Sources of dioxins in the United Kingdom: the steel industry and other sources. Chemosphere 46:371-381
Ayris PM, Delmelle P (2012) The immediate environmental effects of tephra emission. Bull Volcanol 74:1905-1936. https://doi.org/10. 1007/s00445-012-0654-5

Brunauer S, Emmett PH, Teller E (1938) Adsorption of gases in multimolecular layers. J Am Chem Soc 60:309-319. https://doi.org/ $10.1021 / \mathrm{ja} 01269 \mathrm{a} 023$

Crummett WB (1982) Environmental chlorinated dioxins from combustion-the trace chemistries of fire hypothesis. In: Chlorinated Dioxins \& Related Compounds. Elsevier, pp. 253-263

DeGroot D, He G, Fraccalvieri D, Bonati L, Pandini A, Denison MS (2011) AhR ligands: promiscuity in binding and diversity in response. Chapter 4 in the AH Receptor in Biology and Toxicology. 63-79

Denison MS, Zhao B, Baston DS, Clark GC, Murata H, Han D (2004) Recombinant cell bioassay systems for the detection and relative quantitation of halogenated dioxins and related chemicals. Talanta 63:1123-1133

Denison MS, Soshilov AA, He G, DeGroot DE, Zhao B (2011) Exactly the same but different: promiscuity and diversity in the molecular mechanisms of action of the aryl hydrocarbon (dioxin) receptor. Toxicol Sci 124:1-22

Dumortier P, Elskens M, Focant J-F, Goeyens L, Vandermeiren K, Pussemier L (2012) Potential impact of fertilization practices on human dietary intake of dioxins in Belgium. Sci Total Environ 423:47-54

Durant AJ, Villarosa G, Rose WI, Delmelle P, Prata AJ, Viramonte JG (2012) Long-range volcanic ash transport and fallout during the 2008 eruption of Chaitén Volcano Chile. Phys Chem Earth Parts $\mathrm{A} / \mathrm{B} / \mathrm{C} 45: 50-64$

EFSA (2012) Guidance on selected default values to be used by the EFSA Scientific Committee, Scientific Panels and Units in the absence of actual measured data. EFSA Sci Comm J 10(3): 2579, $32 \mathrm{pp}$

Fubini B (1997) Surface reactivity in the pathogenic response to particulates. Environ Health Perspect 105(suppl 5):1013-1020

Gizzi G, Hoogenboom LP, Von Holst C, Rose M, Anklam E (2005) Determination of dioxins (PCDDs/PCDFs) and PCBs in food and feed using the DR CALUX ${ }^{\circledR}$ bioassay: results of an international validation study. Food Addit Contam 22:472-481

Guiñez M, Escudero L, Mandelli A, Martinez LD, Cerutti S (2020) Volcanic ashes as a source for nitrated and oxygenated polycyclic aromatic hydrocarbon pollution. Environ Sci Pollut Res 27(14):16972-16982

Harrad SJ, Sewart AP, Alcock R, Boumphrey R, Burnett V, DuarteDavidson R, Halsall C, Sanders G, Waterhouse K, Wild SR (1994) Polychlorinated biphenyls (PCBs) in the British environment: sinks, sources and temporal trends. Environ Pollut 85:131-146

Heiken G (2013) Dangerous neighbors: volcanoes and cities. Cambridge University Press, p 196

Horwell CJ (2007) Grain-size analysis of volcanic ash for the rapid assessment of respiratory health hazard. J Environ Monit 9:11071115. https://doi.org/10.1039/010583p

Horwell CJ, Baxter PJ (2006) The respiratory health hazards of volcanic ash: a review for volcanic risk mitigation. Bull Volcanol 69:1-24. https://doi.org/10.1007/s00445-006-0052-y

Horwell CJ, Sparks RSJ, Brewer TS, Llewellin EW, Williamson BJ (2003) Characterization of respirable volcanic ash from the Soufriere Hills volcano, Montserrat, with implications for human health hazards. Bull Volcanol 65:346-362. https://doi.org/10. 1007/s00445-002-0266-6

Howsam M, Jones KC (1998) Sources of PAHs in the environment, in: PAHs and Related Compounds. Springer, pp. 137-174

IARC (1983) Polynuclear aromatic compounds, part 1, chemical, environmental, and experimental data. IARC Monographs on the 
Evaluation of the Carcinogenic Risk of Chemicals to Man, IARC Scientific Publications 32:33-451

ISO (1995) International Standard ISO 7708 - Air quality-particle size fractions definitions for the health-related sampling. Geneva Switzerland International Organization for Standardization

Jarvis PA, Bonadonna C, Dominguez L, Forte P, Frischknecht C, Bran D, Aguilar R, Beckett F, Elissondo M, Gillies J (2020) Aeolian remobilisation of volcanic ash: outcomes of a workshop in the Argentinian Patagonia. Front Earth Sci 8:569

JECFA (2006) Polycyclic aromatic hydrocarbons. In: Sixty-fourth report of the Joint FAO/WHO Expert Committee on Food Additives, TRS 930-JECFA 64/61

Jones KC, De Voogt P (1999) Persistent organic pollutants (POPs): state of the science. Environ Pollut 100:209-221

Joshi N, Romanias MN, Riffault V, Thevenet F (2017) Investigating water adsorption onto natural mineral dust particles: linking DRIFTS experiments and BET theory. Aeolian Res 27:35-45

Kaupp H, McLachlan MS (2000) Distribution of polychlorinated dibenzo-P-dioxins and dibenzofurans (PCDD/Fs) and polycyclic aromatic hydrocarbons (PAHs) within the full size range of atmospheric particles. Atmos Environ 34:73-83

Khedidji S, Croes K, Yassaa N, Ladji R, Denison MS, Baeyens W, Elskens M (2017) Assessment of dioxin-like activity in PM10 air samples from an industrial location in Algeria, using the DRE-CALUX bioassay. Environ Sci Pollut Res 24:11868-11877

Knaapen AM, Borm PJ, Albrecht C, Schins RP (2004) Inhaled particles and lung cancer Part A: Mechanisms. Int J Cancer 109:799-809

Kozak K, Ruman M, Kosek K, Karasiński G, Stachnik Ł, Polkowska $\dot{Z}$ (2017) Impact of volcanic eruptions on the occurrence of PAHs compounds in the aquatic ecosystem of the southern part of West Spitsbergen (Hornsund Fjord, Svalbard). Water 9 (1):42. 1-21

Lahde A, Gudmundsdottir SS, Joutsensaari J, Tapper U, Ruusunen J, Ihalainen M, Karhunen T, Torvela T, Jokiniemi J, Jarvinen K, Gislason SR, Briem H, Gizurarson S (2013) In vitro evaluation of pulmonary deposition of airborne volcanic ash. Atmos Environ 70:18-27. https://doi.org/10.1016/j.atmosenv.2012.12.048

Lamparski LL, Nestrick TJ, Cutie SS (1990) The impact on the environment of airborne particulate matter from the eruption of Mount Saint Helens in May 1980. Emiss. Combust. Process. Orig. Meas. Control. Lewis, Chelsea 491

Lohmann R, Jones KC (1998) Dioxins and furans in air and deposition: a review of levels, behaviour and processes. Sci Total Environ 219:53-81

Lohmann R, Northcott GL, Jones KC (2000) Assessing the contribution of diffuse domestic burning as a source of PCDD/Fs, PCBs, and PAHs to the UK atmosphere. Environ Sci Technol 34:2892-2899

Machala M, Vondráček J, Bláha L, Ciganek M, Neča J (2001) Aryl hydrocarbon receptor-mediated activity of mutagenic polycyclic aromatic hydrocarbons determined using in vitro reporter gene assay. Mutat Res Toxicol Environ Mutagen 497:49-62

Martin RS, Watt SFL, Pyle DM, Mather TA, Matthews NE, Georg RB, Day JA, Fairhead T, Witt MLI, Quayle BM (2009) Environmental effects of ashfall in Argentina from the 2008 Chaiten volcanic eruption. J Volcanol Geotherm Res 184:462-472. https://doi.org/ 10.1016/j.jvolgeores.2009.04.010

Maters EC, Delmelle P, Rossi MJ, Ayris PM, Bernard A (2016) Controls on the surface chemical reactivity of volcanic ash investigated with probe gases. Earth Planet Sci Lett 450:254-262

Meyer C, Beer T, Müller J, Gillett R, Weeks I, Powell J, Tolhurst K, McCaw L, Cook GD, Marney D (2004) Dioxins emissions from bushfires in Australia. National Dioxins Program Technical Report No. 1, Australian Government Dept. of the Environment and Heritage, Canberra
Müller D, Hess KU, Kueppers U, Dingwell DB (2020) Effects of the dissolution of thermal barrier coating materials on the viscosity of remelted volcanic ash. Am Mineral J Earth Planet Mater 105(7):1104-1107

Nessel CS, Amoruso MA, Umbreit TH, Meeker RJ, Gallo MA (1992) Pulmonary bioavailability and fine particle enrichment of 2, 3, 7, 8-tetrachlorodibenzo-p-dioxin in respirable soil particles. Fundam Appl Toxicol 19:279-285

Ohura T, Morita M, Makino M, Amagai T, Shimoi K (2007) Aryl hydrocarbon receptor-mediated effects of chlorinated polycyclic aromatic hydrocarbons. Chem Res Toxicol 20:1237-1241

Pereira WE, Rostad CE, Taylor HE (1980) Mount St. Helens, Washington, 1980 volcanic eruption: characterization of organic compounds in ash samples. Geophys Res Lett 7:953-954

Ravindra K, Sokhi R, Van Grieken R (2008) Atmospheric polycyclic aromatic hydrocarbons: source attribution, emission factors and regulation. Atmos Environ 42:2895-2921

Rengarajan T, Rajendran P, Nandakumar N, Lokeshkumar B, Rajendran P, Nishigaki I (2015) Exposure to polycyclic aromatic hydrocarbons with special focus on cancer. Asian Pac J Trop Biomed 5:182-189

Safe SH (1998) Development validation and problems with the toxic equivalency factor approach for risk assessment of dioxins and related compounds. J Anim Sci 76:134-141

Searl A, Nicholl A, Baxter PJ (2002) Assessment of the exposure of islanders to ash from the Soufriere Hills volcano, Montserrat, British West Indies. Occup Environ Med 59:523-531

Steinle S, Sleeuwenhoek A, Mueller W, Horwell CJ, Apsley A, Davis A, Cherrie JW, Galea KS (2018) The effectiveness of respiratory protection worn by communities to protect from volcanic ash inhalation. Part II: Total inward leakage tests. Int J Hyg Environ Health 221:977-984

Stewart C, Damby DE, Tomašek I, Horwell CJ, Plumlee GS, Armienta MA, Hinojosa MGR, Appleby M, Delmelle P, Cronin S (2020) Assessment of leachable elements in volcanic ashfall: a review and evaluation of a standardized protocol for ash hazard characterization. J VolcanolGeotherm Res 392:106756

Stracquadanio M, Dinelli E, Trombini C (2003) Role of volcanic dust in the atmospheric transport and deposition of polycyclic aromatic hydrocarbons and mercury. J Environ Monit 5:984-988

Takizawa Y, Muto H, Asada S (1994) Dioxins in dust fall and volcanic ash samples from the active volcanoes Fugendake and Sakurajima. Organohalogen Compd 20:359-362

Tomašek I, Horwell CJ, Damby DE, Barošová H, Geers C, Petri-Fink A, Rothen-Rutishauser B, Clift MJD (2016) Combined exposure of diesel exhaust particles and respirable Soufrière Hills volcanic ash causes a (pro-)inflammatory response in an in vitro multicellular epithelial tissue barrier model. Part Fibre Toxicol 13:67. https://doi.org/10.1186/s12989-016-0178-9

Tomašek I, Horwell CJ, Bisig C, Damby DE, Comte P, Czerwinski J, Petri-Fink A, Clift MJD, Drasler B, Rothen-Rutishauser B (2018) Respiratory hazard assessment of combined exposure to complete gasoline exhaust and respirable volcanic ash in a multicellular human lung model at the air-liquid interface. Environ Pollut 238:977-987. https://doi.org/10.1016/j.envpol.2018.01.115

UNISDR (2015) Making development sustainable: the future of disaster risk management. Global Assessment Report on Disaster Risk Reduction United Nations Office for Disaster Risk Reduction, Geneva

Urupina D, Lasne J, Romanias MN, Thiery V, Dagsson-Waldhauserova P, Thevenet F (2019) Uptake and surface chemistry of SO2 on natural volcanic dusts. Atmos Environ 217:116942

US EPA (1982) Office of the Federal Registration (OFR) Appendix A: priority pollutants. Fed Reg 47:52309

US EPA (2014a) Method 4435. Screening for dioxin-like chemical activity in soils and sediments using the CALUX® bioassay and 
TEQ determinations. United States Environmental Protection Agency. 1-59

US EPA (2014b) Human health evaluation manual, supplemental guidance: update of standard default exposure factors. Memorandum to OSWER Directive 9200. United States Environmental Protection Agency. 1-120

Van den Berg M, Birnbaum LS, Denison M, De Vito M, Farland W, Feeley M, Fiedler H, Hakansson H, Hanberg A, Haws L (2006) The 2005 World Health Organization reevaluation of human and mammalian toxic equivalency factors for dioxins and dioxin-like compounds. Toxicol Sci 93:223-241

van Leeuwen FR, Feeley M, Schrenk D, Larsen JC, Farland W, Younes M (2000) Dioxins: WHO's tolerable daily intake (TDI) revisited. Chemosphere 40:1095-1101

Voogt P, Brinkman UT (1989) Production, properties and usage of polychlorinated biphenyls. In Halogenated biphenyls, terphenyls, naphthalenes, dibenzodioxins and related products. In: Kimbrough and Jensen (eds.) Elsevier Science Publishers B.V. 3-45

White SS, Birnbaum LS (2009) An overview of the effects of dioxins and dioxin-like compounds on vertebrates, as documented in human and ecological epidemiology. J Environ Sci Health Part C 27:197-211

WHO (1994) Assessing human health risks of chemicals: derivation of guidance values for health-based exposure limits / published under the joint sponsorship of the United Nations Environment Programme, the International Labour Organisation, and the World Health Organization. Environmental Health Criteria, No. 170. 73 p

WHO (2000) Air Quality Guidelines for Europe - Second Edition. Chapter 5.9 Polycyclic aromatic hydrocarbons (PAHs). World
Health Organization Regional Office for Europe, Copenhagen, Denmark. WHO Regional Publications, European Series, No. 91, 92-96

WHO (2019) Exposure to dioxins and dioxin-like substances: a major public health concern. WHO/CED/PHE/EPE/19.4.4, $7 \mathrm{p}$

Wilson TM, Stewart C, Sword-Daniels V, Leonard GS, Johnston DM, Cole JW, Wardman J, Wilson G, Barnard ST (2012) Volcanic ash impacts on critical infrastructure. Phys Chem Earth Parts ABC 45:5-23

Wilson TM, Jenkins S, Stewart C (2015) Volcanic ash fall impacts. Global volcanic hazards and risks. Cambridge University Press, Cambridge, pp 281-288

Windal I, Denison MS, Birnbaum LS, Van Wouwe N, Baeyens W, Goeyens L (2005) Chemically activated luciferase gene expression (CALUX) cell bioassay analysis for the estimation of dioxin-like activity: critical parameters of the CALUX procedure that impact assay results. Environ Sci Technol 39:7357-7364

Witham CS, Oppenheimer C, Horwell CJ (2005) Volcanic ash-leachates: a review and recommendations for sampling methods. $\mathrm{J}$ Volcanol Geotherm Res 141:299-326

Yang S, Song W, Lavallee Y, Zhou X, Dingwell DB, Guo H (2020) Dynamic spreading of re-melted volcanic ash bead on thermal barrier coatings. Corros Sci 170:108659

Ziccardi MH, Gardner IA, Denison MS (2002) Application of the luciferase recombinant cell culture bioassay system for the analysis of polycyclic aromatic hydrocarbons. Environ Toxicol Chem Int J 21:2027-2033 